\title{
PENGARUH APLIKASI CUKA KAYU TERHADAP HAMA PADA TANAMAN KAKAO (Theobroma cacao L.) DI DESA NAWOKOTE KECAMATAN WULANGGITANG KABUPATEN FLORES TIMUR
}

\author{
Fransiskus D. H. Koten ${ }^{1}$, Yohanes Boli Tematan ${ }^{1}$ \\ ${ }^{1}$ Universitas Nusa Nipa, Maumere, 86111, Indonesia
}

Email: yohanestematan@gmail.com

\begin{abstract}
Abstrak
Pestisida merupakan bahan utama untuk membasmi hama pada tanaman karena memiliki unsur - unsur kimia yang penting di dalamnya. Salah satu pestisida yang bisa digunakan adalah cuka kayu.Cuka kayu merupakan cairan kondenzat dari asap yang didapat dari bahan kayu. Penelitian ini bertujuan untuk mengamati dosis cuka kayu yang tepat untuk membasmi hama pada tanaman kakao dan jumlah jenis hama pada tanaman kakao yang dapat diatasi dengan cuka kayu. Penelitian ini dengan rancangan acak kelompok (RAK) dengan 3 transek dan setiap transek di tempatkan 5 plot sehingga di peroleh 15unit percobaan. Perlakuan yang diberikan adalah cuka kayu/air $0 / 500 \mathrm{ml}, 10 / 500 \mathrm{ml}, 20 / 500 \mathrm{ml}, 30 / 500 \mathrm{ml}$, $40 / 500 \mathrm{ml}$. Hasil penelitian menunjukan bahwa aplikasi cuka kayu tidak memiliki pengaruh nyata ( $P>$ 0.05 ) terhadap jumlah hama yang mati pada tanaman kakao (Theobroma cacao L.). Hanya 1 jenis hama yaitu semut api solenopsis geminata yang memiliki dampak postif akibat pemberian pestisida cuka kayu dengan dosis 40/50 $\mathrm{ml}$ air. Jenis hama pada tanaman kakao yang ditemukan adalah 5 jenis hama kakao yaitu, kutu putih Planococcus, Penggerek buah kakao Conopomorpha cramerella, ulat jengkal Hyposidra talaca, semut api Solenopsis geminata, dan Helopeltis.
\end{abstract}

Kata Kunci: Cuka kayu; Hama; pestisida; tanaman kakao

\section{Pendahuluan}

Kakao (Theobroma cacao L.) adalah tanaman perkebunan yang menghasilkan biji kakao dan menjadi salah satu sumber keuangan petani dan negara. Luas Perkebunan kakao Indonesia berkembang seiring dengan meningkatnya permintaan bahan baku. Luas areal tanaman kakao Indonesia pada tahun 2008 mencapai 1.442 .876 Ha dengan produksi sebesar 794.210 ton yang berasal dari perkebunan rakyat 733.574 ton $(92,4 \%)$ perkebunan negara 31.207 ton $(3,9 \%)$ dan perkebunan swasta 29.430 ton $(3,7 \%)$. Angka produksi ini memberikan kontribusi $\pm 12 \%$ terhadap produksi dunia, yaitu sebesar \pm 3 juta ton per tahun. Produksi tersebut menempatkan Indonesia sebagai produsen kakao ketiga di dunia setelah Pantai Gading dan Ghana (Toana, 2014).

$$
\text { Pengembangan kakao di }
$$
Indonesia, tersebar di beberapa wilayah termasuk propinsi Sulawesi Selatan, Sulawesi Tenggara, Sulawesi Tengah, Lampung, Propinsi Bali dan NTT. Salah satu daerah di NTT yang berpotensi untuk budidaya kakao adalah Kabupaten Flores Timur, Kecamatan Wilanggitang. Usaha pengembagan 
agisbisnis kakao di Wulanggitang mengalami beberapa kendala diantaranya penggunaan bibit local yang rentan terhadap hama produktivitas yang rendah, teknik budidaya masih bersifat tradisional, upaya pemberatasan organisme pengganggu tanaman (OPT) dengan cara P3S (Pemangkasan, Pemupukan, Panen Sering dan Sanitasi) serta penggunaan pestisida namun kurang memadai akibat keterbatasan pengetahuan.

Organisma pengganggu tanaman yang sering menyerang tanaman kakao yaitu hama penggerek buah kakao (Acrocercops cramerella), hama penghisap buah (Helopeltis sp) dan busuk buah. Hama penggerak buah kakao dapat mengakibatkan berkurangnya kualitas dan kuantitas biji kakao yang paling diresahkan petani kakao. Hama penghisap buah menyerang pada fase pentil sampai buah muda dengan cara menghisap cairan tanaman sehingga pentil dapat gugur dan menghambat pertumbuhan buah (Joko, 2016). Organisme pengganggu tanaman (OPT) pada tanaman kakao dapat diatasi dengan menggunakan cuka kayu yang diperoleh dari hasil destilasi limbah kayu. Pembuatan bioinsektisida atau insektisida organic yang ramah lingkungan dapat menggunakan limbah kayu seperti sekam padi, kayu nangka,

\section{Metode}

Penelitian ini dilaksanakan di kebun milik warga Desa Nawokote, Kecamatan Wulanggitang, Kabupaten Flores Timur dengan Rancangan Acak Kelompok (RAK) yang terdiri dari 5 perlakuan dengan 3 ulangan dengan kayu mahoni, kayu jati, serbuk kayu dan kelongkong kelapa. Bahan tersebut memiliki berbagai komponen kimia yang dapat berperan sebagai bioinsektisida (Nugrahaini, 2017).

Cukakayu dapat dimanfaatkan sebagai insektisida organic umtuk mengatasi organisme pengganggu tanaman yang ramah lingkungan dan mudah diperoleh. Cuka kayu tidak hanya digunakan untuk mengatasi organisme pengganggu tanaman akan tetapi dapat digunakan untuk merangsang pertumbuhan, menguatkan akar dan daun, menyuburkan tanah, menghalang pembiakan virus dan penyakit dalam tanah, memperbaiki keadaan tanah, menambah kuantitas mikroba yang berguna, menambah kualitas buah dan menambah kandungan gula dalam buah (Komarayati, 2011).

Proses mengaplikasikan cuka kayu pada tanaman kakao adalah tindakan untuk memberantas hama dan mengurangi keguguran pada buah yang ramah lingkungan. Penyemprotan cuka kayu pada bagian putik buah kakao yang terserang hama dapat memperbaiki perkembangan buah. Dosis yang tepat untuk aplikasi cuka kayu pada tanaman kakao adalah $1 \mathrm{ml}$ cuka kayu: $500 \mathrm{ml}$ air (Kementrian Kehutanan dan Pengelola Hasil Hutan, 2012).

dosis yang berbeda yaitu K0:kontrol (tanpa cuka kayu), K1: 10ml/500mlair, K2: $20 \mathrm{ml} / 500 \mathrm{mlair}, \mathrm{K} 3: 30 \mathrm{ml} / 500 \mathrm{ml}$ air dan K4: $40 \mathrm{ml} / 500 \mathrm{ml}$ air. Cuka kayu diujicobakan untuk mengetahui dosis yang tepat mengatasi hama pada 
tanaman kakao. Bahan yang dibutuhkan adalah air dan cuka kayu. Alat yang digunakan antara lain semprotan, alat takaran, tali raffia, meter, alat tulis kamera dan handskul.

Metode yang digunakan dalam penelitian adalah transek dan plot. Terdapat 3 buah transek (sebagai ulangan) dan setiap transek terdapat 5 buah plot (sebagai perlakuan) sehingga diperoleh 15 unit perlakuan. Setiap perlakuan dengan aplikasi cuka kayu dengan dosis berbeda. Setiap unit

\section{Hasil dan Pembahasan}

Secara umum hasil pengamatan terhadap semua jenis hama pada setiap dosis perlakuan menjukan bahwa tidak semua jenis hama pada tanaman kakao (Theobroma cacao L.) dapat diatasi pelakuan diamati dan dihitung jumlah dan jenis hama sebelum dan sesudah aplikasi (Gomes, 2015). Data yang diperoleh pada setiap perlakukan dianalisis dengan analisis of varians (ANOVA). Jika $\mathrm{P}<0,05$, maka dinyatakan bahwa aplikasi cuka kayu memiliki pengaruh terhadap hama pada tanaman kakao, dan sebaliknya jika $\mathrm{P}$ > 0,05, maka tidak pengaruh aplikasi cuka kayu terhadap hama pada tanaman kakao.

pada interval waktu 2 jam sesudah aplikasi cuka kayu. Data pengamatan semua jenis hama sebelum dan sesudah aplikasi cuka kayu pada Tabel 1.

Table 1. Jumlah Serangga yang mati berdasarkan dosis cuka kayu yang diberikan

\begin{tabular}{llllll}
\hline Jumlah semua jenis hama & \multicolumn{7}{l}{ Dosis cuka kayu (ml) } \\
\cline { 2 - 6 } & $\mathbf{0}$ & $\mathbf{1 0}$ & $\mathbf{2 0}$ & $\mathbf{3 0}$ & $\mathbf{4 0}$ \\
\hline Mati & $1,333^{\mathrm{a}}$ & $12,333^{\mathrm{a}}$ & $6,333^{\mathrm{a}}$ & $7,667^{\mathrm{a}}$ & $6,333^{\mathrm{a}}$ \\
\hline
\end{tabular}

Menurunnya jumlah hama dapat terjadi karena mati atau berpindah. Hama dapat mati karena cuka kayu mengandung komponen kimia diantaranya asam asetat berkisar antara 21,71 - 30,05 ppm, metanol 0,44$1,15 \%$ dan fenol 45,07-63,62 ppm (Komarayati, 2011). Cuka kayu dapat mengurangi hama penyakit pada tanaman, dengan cara melarutkan cuka kayu dalam air dengan perbandingan $1 / 500 \mathrm{ml}$ (Pusat Penelitian Dan Pengembangan Keteknikan Kehutanan Dan Pengolahan Hasil Hutan, 2012). Variasi kandungan komponen kimia cuka kayu disebabkan oleh jenis limbah kayu yang digunakan. Kandungan komponen kimia yang bervariasi ini menyebabkan perbedaan jenis hama yang dapat diatasi dengan cuka kayu. Komponen kimia cuka kayu seperti asam asetat berfungsi untuk mempercepat pertumbuhan tanaman, pencegah penyakit tanaman. Metanol berfungsi untuk mempercepat pertumbuhan tanaman (Komarayati, 2011).

Terdapat 5 jenis hama pada tanaman kakao (Theobroma cacao L) di Desa Nawakote Kecamatan 
Wulanggitang yang dapat di atasi dengan menggunakan cuka kayu yakni: 1. Kutu Putih (Planococcus)

Hama kutu putih memiliki musuh alami antara lain coleoptera, thysanoptera, diptera, dan neuroptera yang bersifat sebagai predator serta jamur entomophthorales. Musuh alami merupakan faktor biotik yang berperan penting dalam pengendalian populasi hama. Kutu putih dapat di atasi juga dengan menggunakan pestisida dan cuka kayu. Konsentrasi 10/500 ml cuka kayu efektif untuk mengatasi hama kutu putih. Penurunan jumlah kutu putih pada setiap dosis cuka kayu berbeda tergantung daya tahan tubuh kutu putih. Menurunnya jumlah kutu putih dapat terjadi karena mati atau berpindah. (Ambarwati, 2013). Data pengamatan pada Tabel 2.

Tabel 2. Jenis Serangga yang mati berdasarkan dosis cuka kayu yang diberikan

\begin{tabular}{llllll}
\hline $\begin{array}{l}\text { Serangga Yang } \\
\text { Mati }\end{array}$ & \multicolumn{5}{l}{ Dosis cuka kayu (ml) } \\
\cline { 2 - 6 } & $\mathbf{0}$ & $\mathbf{1 0}$ & $\mathbf{2 0}$ & $\mathbf{3 0}$ & $\mathbf{4 0}$ \\
\hline Kutu Putih & $0,667^{\mathrm{a}}$ & $5,667^{\mathrm{a}}$ & $3,667^{\mathrm{a}}$ & $7,000^{\mathrm{a}}$ & $0,333^{\mathrm{a}}$ \\
\hline Semut Api & $1,000^{\mathrm{a}}$ & $0,667^{\mathrm{a}}$ & $1,333^{\mathrm{a}}$ & $0,000^{\mathrm{a}} \mathrm{b}$ & $-3,333^{\mathrm{b}}$ \\
\hline Kepik Buah & $0,000^{\mathrm{a}}$ & $0,333^{\mathrm{a}}$ & $0,667^{\mathrm{a}}$ & $-0,667^{\mathrm{a}}$ & $-0,333^{\mathrm{a}}$ \\
\hline Ulat Jengkal & $0,000^{\mathrm{a}}$ & $5,333^{\mathrm{a}}$ & $0,000^{\mathrm{a}}$ & $0,667^{\mathrm{a}}$ & $-2,00^{\mathrm{a}}$ \\
\hline Penggerek Buah & $0,000^{\mathrm{a}}$ & $5,333^{\mathrm{a}}$ & $0,000^{\mathrm{a}}$ & $0,667^{\mathrm{a}}$ & $-2,00^{\mathrm{a}}$ \\
\hline
\end{tabular}

2. Semut Api (Solenopsis geminata)

Keberadaan semut api sangat erat kaitannya dengan kondisi habitat. Faktor pembatas utama yang mempengaruhi keberadaan semut yaitu suhu rendah, habitat yang tidak mendukung untuk pembuatan sarang, sumber makanan yang terbatas serta daerah jelajah yang kurang mendukung. Semut api juga dapat di atasi dengan cuka kayu pada konsentrasi $40 \mathrm{ml} / 500$ air. Data hasil analisis pengamatan jumlah semut api menunjukkan bahwa pemberian cuka kayu dengan berpengaruh nyata $(0,014<0,05)$ terhadap keberadaan semut api. Hasil pengamatan semut api pada setiap dosis perlakuan terlihat pada Tabel 2.

3. Kepik Buah (Helopeltis)
Buah kakao yang terserang helopeltis ditandai dengan bercak - bercak berwarna cokelat kehitaman. Helopeltis dapat menyebabkan buah kakao yang masih muda (pentil) menjadi layu, kering dan akhirnya rontok. Apabila pertumbuhan buah terus berlanjut maka kulit buah akan mengeras dan retak-retak, pada akhirnya terjadi perubahan bentuk buah yang dapat menghambat perkembangan biji di dalamnya (Indriati, 2018). Helopeltis dapat diatasi dengan insektisida akan tetapi cara lain yang lebih ramah lingkungan adalah dengan cuka kayu. Dosis cuka kayu yang lebih efektif untuk mengatasi serangan helopeltis adalah kayu $2,5 \mathrm{ml}$.

Data hasil analisis pengamatan jumlah helopeltis menunjukkan bahwa pemberian cuka kayu dengan tidak 
berpengaruh nyata $(0,826>0,05)$ terhadap keberadaan kepik buah Secara umum hasil pengamatan terhadap helopeltis pada setiap dosis perlakuan terlihat pada Tabel 2. Ulat

4. Jengkal (Hyposidra talaca)

Ulat jengkal menyerang daun kakao yang masih muda. Serangan ulat jengkal menyebabkan daun berlubang dan pucuk tanaman gundul, hingga tinggal tulang daun. Bila daun-daun muda dan pucuk telah habis makan ulat jengkal akan meningkatkan serangannya ke daun-daun tua. Ulat jengkal memiliki beberapa musuh alami, diantaranya adalah patogen yang menyerang ulat pada fase larva (Hidayah, 2017). Selain ulat jengkal dapat di atasi dengan dengan musuh alami, ulat jengkal dapat di atasi dengan cuka kayu $10 \mathrm{ml}$ cuka kayu dilarutkan dalam $250 \mathrm{ml}$ aquades. Cuka kayu dapat mencegah serangan hama karna komponen kandungan kimia fenol fenol 45,07-63,62 ppm, dapat mencegah serangan hama dan yang terdapat pada tanaman (Maryam, 2019).

Hasil analisis data pengamatan jumlah ulat jengkal menunjukkan bahwa pemberian cuka kayu dengan tidak berpengaruh nyata $(0,58>0,05)$ terhadap keberadaan ulat jengkal. Secara umum hasil pengamatan terhadap jumlah ulat jengkal pada setiap dosis perlakuan terlihat pada Tabel 2.

\section{Penggerek buah (Acrocercops cramerella)}

Serangan Acrocercops cramerella sangat khas dan sulit dideteksi karena imago betina meletakkan telur pada buah kakao yang masih muda dan gejala baru terlihat pada saat buah siap dipanen. Telur diletakkan pada permukaan buah kakao, kemudian menetas dan larva instar ke-1 menggerek kulit buah masuk ke dalam buah. Larva hidup di dalam buah sehingga sulit untuk dikendalikan (Samsudin, 2018). Pengendalian hama antara lain: (1) mengendalikan populasi hama tetap di bawah ambang kerusakan dalam waktu yang cukup lama, (2) tidak berdampak negatif pada lingkungan, (3) tidak membutuhkan alat dan teknik aplikasi tertentu, dan (4) tidak membutuhkan biaya tambahan lain (samsudin, 2018). Cuka kayu merupakan salah satu pestisida alami untuk membasmi hama dan penyakit pada tanaman termasuk kakao. Dosis cuka kayu yang efektif untuk mengatasi hama penggerek buah kakao adalah 20 $\mathrm{ml}$ cuka kayu/ $500 \mathrm{ml}$ air.

Data hasil analisis mengenai pengamatan jumlah penggerek buah kakao menunjukkan bahwa pemberian cuka kayu dengan tidak berpengaruh nyata $(0,534>0,05)$ terhadap keberadaan penggerek buah kakao. Secara umum hasil pengamatan terhadap jumlah penggerek buah kakao pada setiap dosis perlakuan terlihat pada Tabel 2 . 


\section{Kesimpulan}

Aplikasi cuka kayu dengan dosis terhadap jenis hama yang lain seperti 40/500ml pada tanaman kakao dapat berpenaruh nyata terhadap hama semut api (Solenopsis geminate) kutu putih (Planococcus), kepik buah (Helopeltis), ulat jengkal (Hyposidra talaca) dan Acrocercops cramerella.

\section{Daftar Pustaka}

Ambarwati. N., Subagiya. Dan Pardjo N. S. Y. V. 2013. Efektifitas Cuka Kayu sebagai Pestisida Nabati dalam Pengendalian Hama Crocidolomia Pavonana dan Zat Perangsang Tumbuh pada Sawi. Agrosains 15(1): 17-20 2013. ISSN: (1411) (5786)

Hidayah. H. N., Irawan. A., dan Anggraini. I. 2017. Serangan Ulat Jengkal (Hyposidra talaca WIk.) Pada Bibit Pakoba (Syzygium luzonense (Merr.) Merr.) Di Persemaian. Agrologia, Vol. 6, No.1, April 2017, Hal. 37-43.

Joko. S dan Wibisono. I. I. 2016. Hama dan Penyakit Tanaman Perkebunan. PT Intan sejati, Klaten 57438, Indonesia.

Komarayati. S., Gusmailina. dan Pari.G., 2011. Produksi Cuka Kayu Hasil Modifikasi Tungku Arang Terpadu. Jurnal Penelitian Hasil Hutan. Vol. (29)(3), : 234-247.

Maryam., Ekamawanti . H. A., dan Togar F Manurung. T. F. 2019. Pengaruh Konsentrasi Cuka Kayu Dan Media Tanam Pada Pertumbuhan Setek Pucuk Pangal (Baccaurea Bracteata Muell). Jurnal Hutan Lestari Vol. (7) (1) : 462 471

Nugrahaini. D. L., Kusdiyantini. E., Tarwotjo. U. dan Prianto. A. H. Identifikasi Kandungan Senyawa Kimia Cuka Kayu dari Sekam Padi. 2017. Jurnal Bioma. Vol. 19, No. 1, Hal. 30-37.

Toana. H., Mudjiono. G., Karindah. S., dan Abadi. A. L. 2014. Morfologi dan Ukuran Liang Gerak Larva PBK Conopomorpha cramerella (Lepidoptera: Gracillariidae) pada Buah Kakao. Jurnal AgrolandVol (21)(2) : 77 - 80. E-ISSN : 2407 - 7607. 